Kelola

Jurnal Manajemen Pendidikan

Magister Manajemen Pendidikan

ISSN 2443-0544

FKIP Universitas Kristen Satya Wacana

Volume: 3, No. 1, Januari-Juni 2016

jurnalkelola@gmail.com

Halaman: 67-79

\title{
STRATEGI PEMASARAN SEKOLAH MENENGAH ATAS SWASTA BERASRAMA DI KABUPATEN SEMARANG ${ }^{1}$
}

\author{
Brigitta Putri Atika Tyagita \\ Mahasiswa Program Pascasarjana Magister Manajemen Pendidikan \\ FKIP-Universitas Kristen Satya Wacana \\ brigittaputriatika@gmail.com
}

\begin{abstract}
This study aimed to describe the success of marketing strategies in SMA Sedes Sapientiae Jambu which is a high boarding school in Bedono, Semarang regency with its students coming from various cities in Indonesia, such as Palembang, Lampung, Jakarta, Bogor, Semarang, Yogyakarta, Bali, Makassar and Papua. The diversity of high school students Sedes Sapientiae Jambu is because the success of marketing management at SMA Sedes Sapientiae Jambu Bedono, where in the executing the marketing strategy there is a special team and they did not hesitate to invite an expert in the field of marketing to teach the promotion team to do marketing. In addition, many of the activities carried out in marketing schools such as by visiting junior high schools in various regions of Java and Jakarta region and made a presentation as Sedes Sapientiae Jambu students as keynote speaker, did a choir at churches, did a tty out for the junior and open house in SMA Sedes Sapientiae Jambu, besides that, establishing relationships with alumni who are in various cities in Indonesia. Data collection techniques in this research through interviews, participatory observation and documentation, and data analysis performed continuously throughout the study. One of the keys of the succesful of marketing in SMA Sedes Sapientiae Jambu the activities that establish a good relationship with various secondary schools in various regions, relations with alumni, parents, committee and local residents. The evidenced of it by the increasing number of high school students in Sedes Sapientiae Jambu from year to year. In this paper the writer recommend ways of marketing carried out by SMA Sedes Sapientiae Jambu that can be applied in other schools to increase student numbers.
\end{abstract}

Keywords: best practices, marketing school, high school, boarding school

\section{PENDAHULUAN}

Suatu pendidikan dapat berjalan dengan baik jika terdapat komponen seperi guru, siswa, tenaga kependidikan, sarpras dan gedung pembelajaran yang memadai dan saling

\footnotetext{
${ }^{1}$ Naskah ini sudah pernah dimuat dalam Prosiding Seminar Nasional Membangun Budaya Penelitian untuk Meningkatkan Kualitas Pendidikan Indonesia Dalam Perspektif Revolusi Mental Guru di Indonesia yang diselenggarakan oleh Progdi S2 MMP-FKIP-UKSW tanggal 12 Maret 2016
} 
berhubungan satu sama lain. Setiap sekolah tiap tahunnya pasti akan membuka pendaftaran siswa baru untuk berlangsung pendidikan dalam sekolah tersebut. Untuk mendapatkan murid, setiap sekolah pastinya akan melakukan penerimaan siswa baru setiap tahunnya. Bagi suatu sekolah, penerimaan siswa baru merupakan suatu hal yang penting karena hal ini akan menjadi sebuah titik awal untuk berlangsungnya atau kelancaran tugas sekolah (Yuliana, 2009).

Untuk mendapatkan siswa-siswi di tahun ajaran baru, sekolah akan mengadakan promosi. Promosi yang akan dilakukan sekolah dapat dilakukan melalui berbagai media, namun promosi sekolah melalui berbagai media pengaruhnya memang kecil, seperti hasil penelitian Inayah (2012) yang menunjukan bahwa media promosi tidak begitu mempengaruhi calon siswa memilih sekolah namun opini formasi dari sekolah itu sendirilah yang mempengaruhi para calon siswa dan orang tua siswa (konsumen) untuk memilih sekolah tersebut. Promosi sekolah memang tidak begitu mempengaruhi keputusan siswa dalam memilih sekolah dan pengaruh promosi sekolah memang rendah, namun pasti (Sinduwiatmo, 2011).

Strategi promosi sekolah pun menjadi hal yang penting untuk melakukan promosi sekolah. Promosi sekolah atau promosi jasa pendidikan merupakan alat pemasaran jasa pendidikan yang dapat berfungsi untuk memasarkan dunia pendidikan (Gandhi, 2004). Dan menurut Alma (2005), tujuan dari promosi adalah untuk menginformasikan tentang keberadaan produk baru, membujuk untuk menjadikan produk sebagai pilihan konsumen, dan mengingatkan pembeli bahwa produk dibutuhkan dalam waktu dekat.

Pemasaran jasa pendidikan harus membangun sudat padang masa depan sekolahnya dengan baik. Oleh sebab itu pemikiran strategi pemasarannya pun juga harus baik dan berpandangan ke depan dan belakang. Menurut Quinn dkk (1995) dalam Wijaya (2012) mengemukanan definisi merupakan rencana yang menyatupadukan sasaran utama, kebijakan, dan tindakan organisasi menjadi satu kesatuan. Dalam menentukan strategi juga dibutuhkan tujuan dan sasaran, kebijakan, program serta keputusan strategis. Menurut Quinn strategi dirumuskan dengan 5P yaitu plan (rencana), ploy (cara), pattern (pola), position (posisi) dan perspective (sudut pandang). 
Dalam bidang pendidikan diperlukan konsep strategi pemasaran, yaitu (1) Distinctive competence, yaitu tindakan yang dilakukan oleh perusahaan agar dapat melakukan kegiatan yang lebih baik dari pada pesaing; (2) Competitive advantage, yaitu kegiatan spesifik yang dikembangkan oleh perusahaan agar lebih unggul dibandingkan dengan pesaingnya, melalui strategi differensiasi. Strategi differensiasi adalah strategi yang memberikan penawaran yang berbeda dibandingkan penawaran yang diberikan oleh kompetitor. Strategi differensiasi dilakukan dengan menciptakan persepsi terhadap nilai tertentu pada konsumennya. Misalnya: persepsi mengenai keunggulan kerja, inovasi produk, pelayanan yang lebih baik, brand image yang lebih unggul, dan lain-lain (Dr.Irianto).

Selain dengan konsep - konsep tersebut, komunikasi juga merupakan hal penting dalam pemasaran pendidikan/sekolah. Komunikasi pemasaran adalah fungsi dalam menajemen yang memusatkan perhatian pada produk/jasa untuk memenuhi kebutuhan konsumen. Strategi komunikasi dapat dilakukan dengan publisitas media massa terhadap organisasi, orang, produk, jasa maupun gagasan untuk mendapatkan dukungan publik. Model komunikasi yang digunakan dalam perencanaan komunikasi adalah model informatif, persuasif dan dialog untuk mendapatkan pemahaman yang saling menguntungkan (Dr.Irianto).

Menurut Zeithaml dan Bitner (2000) dalam Wijaya (2012) nengemukakan empat strategi pengelolaan komunikasi pemasaran jasa pendidikan yang efektif, yaitu dengan (1) mengelola janji tentang jasa pendidikan dengan mengkoordinasikan janji yang dibuat seluruh sumber daya pemasaran jasa pendidikan eksternal secara interaktif untuk memastikan janji itu tepat dan layak. (2) mengelola harapan pelanggang jasa pendidikan, (3) meningkatkan tingkat pendidikan dari pelanggan jasa pendidikan, (4) mengelola komunikasi pemasaran internal jasa pendidikan melalui pemimpin sekolah kepada para guru dan karyawan.

Melalui promosi-promosi yang dilakukan oleh sekolah tersebut maka sekolah dapat memperlihatkan kualitas dan kuantitas dari sekolah tersebut, serta prestasi apa saja yang telah diperoleh sekolah tersebut. Seperti halnya yang dilakukan oleh SMA Sedes 
Sapientiae Jambu, SMA Swasta berasrama yang berada di desa Bedono, kecamatan Jambu, kabupaten Semarang. Strategi promosi sekolah yang dilakukan oleh SMA Sedes Sapientiae Jambu ini menghasilkan peningkatan jumlah siswa dari tahun ke tahun seperti data sebagai berikut:

Tabel 1. Perkembangan Jumlah Siswa SMA Sedes Sapientiae Tahun 2005-2015

\begin{tabular}{|c|c|c|}
\hline NO. & Tahun Pelajaran & Jumlah Siswa kelas X yang masuk \\
\hline 1. & $2005-2006$ & 66 siswa \\
\hline 2. & $2006-2007$ & 77 siswa \\
\hline 3. & $2007-2008$ & 83 siswa \\
\hline 4. & $2008-2009$ & 76 siswa \\
\hline 5. & $2009-2010$ & 84 siswa \\
\hline 6. & $2010-2011$ & 108 siswa \\
\hline 7. & $2011-2012$ & 103 siswa \\
\hline 8. & $2012-2013$ & 107 siswa \\
\hline 9. & $2013-2014$ & 113 siswa \\
\hline 10. & $2014-2015$ & 113 siswa \\
\hline 11. & $2015-2016$ & 139 siswa \\
\hline
\end{tabular}

Sumber: Data sekolah, diolah

Oleh sebab itu, dalam penelitian best practice ini akan dipaparkan keberhasilan dari strategi pemasaran atau promosi dari sekolah berasrama SMA Sedes Sapientiae Jambu yang berlokasi di sebuah desa.

\section{METODE PENELITIAN}

Penelitian ini dilakuakan di SMA Sedes Sapientiae Jambu, yang beralamatkan di Jalan raya Ambarawa-Magelang km. 10 Bedono, Kecamatan Jambu, Kabupaten Semarang. Subjek dalam penelitian ini adalah panitia atau tim promosi SMA Sedes Sapientiae Jambu (Ketua, Sekretaris, seksi humas) dengan penanggung jawabnya adalah Kepala Sekolah. Penelitian ini menggunakan metode kualitatif dengan menggunakan wawancara 
mandala (in-depth interview), pengamatan partisipatif (participant observation) dan juga dokumentasi (documentation). Wawancara yang dilakukan didesain untuk mengetahui rencana-rencana dalam pemasaran sekolah serta langkah-langkah yang harus dilakukan dalam mempersiapkan, melaksanakan dan evaluasi kegiatan pemasaran. Digunakannya wawancara mendalam adalah untuk memusatkan perhatian pada kasus yang intensif dan mendetail melalui pengumpulan data, penyusunan daa, analisis dan interpretasi data. Wawancara ini dilakukan lebih dari sekali untuk mendapatkan data yang mendalam dan lengkap.

Instrumen penelitian yang digunakan dalam penelitian ini adalah peneliti sendiri (human instrument). Analisis terhadap data penelitian dilakukan terus menerus selama penelitian berlangsung. Data hasil penelitian yang dianalisa adalah transkrip hasil wawancara, catatan di lapangan, dan dokumentasi sekolah.

\section{HASIL DAN PEMBAHASAN}

SMA Sedes Sapientiae Jambu merupakan salah satu sekolah berasrama di Kabupaten Semarang. SMA Sedes Sapientiae Jambu ini tepatnya berada di desa Bedono, Kecamatan Jambu, Kabupaten Semarang. Secara geografis, letak sekolah ini berada di pedesaan dan jauh dari perkotaan. Bahkan untuk menuju Jogja ataupun Semarang dibutuhkan sekitar satu sampai dua jam perjalanan. Namun, walaupun demikian sekolah ini memiliki banyak murid yang berasal dari berbagai daerah di Indonesia, seperti dari Medan, Palembang, Lampung, Riau, Batam, Jakarta, Bekasi, Bogor, Purwakarta, Tegal, Semarang, Pati, Kudus, Jogja, Purwokerto, Malang, Palangkaraya, Pontianak, Makassar, Bali, Lombok, Timika dan Jaya Pura. Dapat dikatakan bahwa siswa-siswi yang bersekolah di SMA Sedes Sapientiae ini berasal dari Sabang sampai Merauke, dan dari berbagai macam budaya dan adat istiadat.

SMA Sedes Sapientiae Jambu dapat memiliki murid dari berbagai daerah tersebut karena keberhasilan dari strategi pemasarannya dan kerja keras tim promosi SMA Sedes Sapientiae Jambu. SMA Sedes Sapientiae Jambu ingin menjadi lebih baik dan menjadi sekolah pilihan bagi anak-anak di Indonesia. Bagi SMA Sedes Sapientiae Jambu, yang merupakan sekolah Marsudirini dan sekolah Katolik, menanamkan nilai-nilai Kristiani 
merupakan hal yang penting, wlaupun demikian SMA Sedes Sapientiae Jambu ini tidak mengkatolikan siswa-siswi yang bersekolah disini. Namun, dalam mengembangkan kemampuan siswa-siswi yang bersekolah di SMA Sedes Sapientiae Jambu ini dengan nilai-nilai Kristiani, seperti saling mengasihi, mengampuni, dan lain sebagainya seperti halnya yang tertulis dalam visi dan misi SMA Sedes Sapientiae Jambu.

SMA Sedes Sapientiae Jambu memiliki misi yaitu "Mewujudkan siswa berkarakter cerdas, unggul, dan bersaudara dijiwai nilai-nilai kristiani”, dan dari misi tersebut, SMA Sedes Sapientiae Jambu membangun visi-visi sekolah dengan mengembangkan kemampuan intelektual, dalam bernalar dan berkomunikasi, mengembangkan etika yang berakar dari nilai nilai kristiani, menumbuhkan jiwa estetis melalui seni dan budaya dan menyediakan formasi iman, berpartisipasi dalam liturgi, dan aktivitas aktivitas sosial. Melalui visi-misi tersebut, SMA Sedes Sapientiae Jambu memiliki tujuan menyiapkan lulusan supay mampu membangun dan ikut bertanggung jawab atas pembangunan bangsa dan Negara Indonesia, memiliki bekal dan siap untuk melanjutkan pendidikan ke perguruan tinggi, mampu mandiri, bertanggung jawab, kreatif, kritis, dan inovatif dan menjadi pribadi yang utuh dan seimbang dalam intelktual, emosional, religious, sosial dan fisik, dengan semboyan "Crescat et Floreat" yang berarti "Tumbuh dan berkembanglah dalam intelektual dan kepribadian"

Dari visi-misi tersebut terlihat jelas bahwa SMA Sedes Sapientiae ingin mewujudkan lulusan yang unggul dan cerdas, namun tidak hanya cerdas secara akademik, namun juga secara rohani. Melalui visi - misi tersebut pulalah, tim promosi dan keluarga besar SMA Sedes Sapientiae Jambu bekerja keras untuk dapat mempromosikan dan mengembangkan diri. Promosi yang dilakukan berupa promosi langsung maupun tidak langsung.

\section{Strategi Pemasaran}

Dalam tahap perencanaan ini, tim promosi SMA Sedes Sapientiae Jambu dibentuk dalam raker (rapat kerja) yang diadakan pada awal tahun pelajaran baru. Sebelumnya, tim promosi telah dibentuk pada akhir tahun pelajaran dan rencana-rencana strategi promosi atau pemasarannya dilakukan atau di paparkan pada raker tersebut. Rencana-rencana 
strategi promosi ini harus jelas, seperi sekolah mana saja yang akan dikunjungi, akan memasang spanduk dimana saja, akan mengadakan safari koor di gereja mana saja dan juga biaya yang akan dikeluarkan selama kegiata tersebut berlangsung. Selain itu, tim promosi ini juga bertugas menjadi tim PSB (Penerimaan Siswa Baru), sehingga tim promosi juga harus menentukan tanggal penerimaan siswa baru dan alurnya.

Pada tahap persiapan ini pula, SMA Sedes Sapientiae Jambu juga melakukan pendampingan serta pelatihan untuk melakukan atau merencanakan strategi pemasaran yang baik. Sekolah mengundang seorang pakar dalam bidang pemasaran dan melakukan pelatihan sehari khusus untuk persiapan pemasaran sekolah yang diikuti oleh guru-guru dan staff, baik staff sekolah maupun asrama SMA Sedes Sapientiae Jambu. Dalam pelatihan tersebut, mereka diajarkan untuk mencari tahu keungulan yang dimiliki sekolah dan yang tidak dimiliki oleh sekolah-sekolah lain yang berada disekitar mereka, kemudian setelah ditemukan keunggulan SMA Sedes Sapientiae Jambu, maka keunggulan itulah yang harus mereka pertahankan dan tingkatkan. Selain itu, dalam pelatihan tersebut para guru dan staff juga dijarkan mengenai melakukan perencanaan strategi promosi yang baik, strategi promosi yang efektif dan mengangkat keunggulan dari sekolah untuk menjadi nilai plus dalam sekolah tersebut, serta bagaimana menjalin relasi yang baik dengan warga sekitar, wali murid, komite, sekolah-sekolah lain ataupun instansi pendidikan lainnya dan juga para alumni. Melalui pelatihan tersebut maka tim promosi pun memiliki bekal untuk menentukan strategi dan melaksanakan strategi tersebut dengan lebih baik dari pada sebelumnya.

SMA Sedes Sapientiae Jambu sebagai sekolah swasta Katolik, dalam mempersiapkan strategi dan melaksanakan kegiatan promosi atau pemasaran sekolah, mengawalinya dengan berziarah ke gua Maria terlebih dahulu. SMA Sedes Sapientiae Jambu mengawalinya dengan berdoa, memohon kelancaran dan kesuksesan dalam proses pemasaran ini sehingga SMA Sedes Sapientiae Jambu mendapatkan jumlah siswa sesuai dengan target atau bahkan dapat melebihi target. Kemudian, diakhir tahun dimana kegiatan promosi ini selesai, SMA Sedes Sapientiae Jambu akan kembali berziarah ke Gua Maria untuk mengucapkan syukur dan trimakasih atas terselenggaranya kegiatan promosi dan kegiatan lainnya selama setahun. 
Pelaksanaan kegiatan sesuai dengan strategi yang dibentuk dapat dibagi menjadi 2, yaitu internal dan eksternal. Pelaksanaan secara internal secara khusus, tim promosi SMA Sedes Sapientiae Jambu dalam mempromosikan sekolah dengan bekerja sama dengan tim hubungan masyarakat dan melibatkan orang tua murid, siswa-siswi, alumni dan juga masyarakat sekitar. Ada beberapa strategi pemasaran yang dilakuakan oleh SMA Sedes Sapientiae Jambu secara internal yaitu dengan mengadakan open house setiap setahun sekali dan dibuka untuk umum. Dalam kegiatan open house ini pun juga diadakan bazar dan pengobatan gratis bagi masyarakat sekitarnya, dan dalam kegiatan ini pula SMA Sedes Sapientiae Jambu juga mengadakan lomba mewarnai untuk anak-anak TK, lomba futsal dan tari Keprajuritan bagi anak-anak SD yang berada di sekitar SMA Sedes Sapientiae Jambu. Selain itu ada pula kegiatan lomba mata pelajaran UN SMP yang diikuti oleh SMPSMP di Kabupaten Semarang dan Kedu.

Kegiatan pemasaran lainnya yang di lakukan oleh SMA Sedes Sapientiae Jambu adalah dengan mengadakan festival band antar SMP se Kabupaten Semarang. Sedangkan dari segi olahraga adalah dengan mengadakan Sedes Cup, yaitu lomba basket antar SMP se-Kabupaten Semarang.

Faktor internal lainnya yang membantu keberhasila dalam promosi adalah hasil lulusan dari SMA Sedes Sapientiae Jambu. Para lulusan merupakan cermin bagi SMA Sedes Sapientiae Jambu untuk memperlihatkan mutu dan citranya. Masyarakat sekitar akan menilai perilaku para siswa dan juga alumni SMA Sedes Sapientiae Jambu dan melalui penilaian tersebut maka masyarakat dapat menilai sendiri mutu dan citra dari SMA Sedes Sapientiae Jambu ini. Untuk menghasilkan mutu lulusan yang baik para guru pun mendidik para siswa berdasarkan visi misi SMA Sedes Sapientiae Jambu, yaitu dengan mengajarkan kemandirian, tanggung jawab, kreatif, inivatif, budaya berfikir kritis, dan memiliki emosional dan intelektual yang seimbang melalui proses belajar mengajar di sekolah. selain itu, SMA Sedes Sapientiae Jambu sebagai sekolah swasta Katolik juga mendidik para siswa-siswinya berdasarkan ajaran Katolik, yaitu dengan kasih.

Kemudian, secara eksternal ada beberapa cara yang dilakukan dalam berpromosi diantaranya dengan memasang spanduk-spanduk di beberapa gereja atau SMP di beberapa 
kota, seperti halnya yang dilakukan oleh beberapa SMA berasrama yang ada di sekitar Jawa Tengah. Hal ini sudah menjadi biasa dan selalu dilakukan. Biasanya SMA Sedes Sapientiae Jambu memasangkan spanduk tersebut di sekitar gereja, SMP-SMP yang bekerja sama dengan SMA Sedes Sapientiae Jambu, tempat - tempat ziarah Katolik dan beberapa kota dengan ijin khusus tentunya.

Kegiatan lainnya adalah dengan mengikuti kegiatan open house yang diadakan oleh beberapa SMP di sekitar Jawa Tengah. Dalam kegiatan open house yang diadakan oleh SMP yang bersangkutan, biasanya akan di sediakan stand bagi SMA yang berpartisipasi untuk memerkan hasil karya siswa ataupun video yang berhubungan dengan sekolah. Bagi SMA Sedes Sapientiae Jambu, kegiatan seperti ini juga merupakan kesempatan emas yang dapat dimanfaatkan secara optimal, karena nanti dari pihak SMP juga akan memberikan waktu untuk presentasi kepada wakil dari SMA yang berpartisipasi untuk memperkenalkan sekolahnya didepan para siswa dan wali murid, selain itu para siswa-siswi SMP tersebut baik dari kelas VII sampai dengan kelas IX dapat mengunjungi stand SMA Sedes Sapientiae Jambu dan mengenal lebih dalam tentang SMA Sedes Sapientiae Jambu. Biasanya pula, SMA Sedes Sapientiae Jambu dalam mengikuti kegiatan seperti ini mengikutsertakan para siswa yang merupakan alumni dari SMP tersebut dan melanjutkan ke SMA Sedes Sapientiae Jambu, sehingga diharapkan para siswa tersebut memiliki relasi dengan para guru dan adik-adik kelasnya, sehingga adik-adik kelasnya pun tak segan untuk mengenal lebih lanjut mengenai SMA Sedes Sapientiae Jambu, bahkan tak segan untuk langsung mendaftarkan dirinya.

Strategi pemasaran selanjutnya ialah dengan melakukan safari koor ke gerejagereja Katolik di area Semarang - Kedu. Paduan suara SMA Sedes Sapientiae Jambu, SS Lauda, merupakan salah satu ekstra unggulan yang ada di SMA Sedes Sapientiae Jambu dan menjadi kebanggaan bersama. Ketika melakukan safari koor di gereja, tim promosi pun juga membuka sebuah stand untuk mempertunjukan beberapa hasil karya anak-anak, seperti pupuk organic, lilin, atau video kegiatan yang dilakukan oleh siswa-siswi SMA Sedes Sapientiae Jambu selama di sekolah. Tidak hanya itu saja, tim promosi pun juga mengajak beberapa siswa-siswinya untuk membantu membagikan brosur kepada para umat 
di gereja dan dengan ramah melayani pelayanan terkait dengan SMA Sedes Sapientiae Jambu dari para umat yang pulang atau keluar dari gereja.

Kemudian, tim promosi SMA Sedes Sapientiae Jambu pun tak segan untuk mengikuti presentasi di beberapa SMP baik di sekitar Semarang, Kedu, dan Jogja maupun sampai ke daerah Jabodetabek, seperti Jakarta, Depok dan Bekasi. Bahkan, tim promosi SMA Sedes Sapientiae Jambu juga pernah melakukan presentasi ke beberapa SMP di Jaya Pura, Papua pada tahun 2012. Melalui presentasi langsung dihadapan para siswa-siswi SMP kelas sembilan dan bahkan di depan orang tua murid, maka akan menjadi efisien dan jelas, karena ketika siswa atau orang tua ada pertanyaan mengenai sekolah ataupun asrama dapat dijawab langsung oleh para tim promosi yang melakukan presentasi ini. Dalam presentasi ini, tim promosi SMA Sedes Sapientiae Jambu tidak hanya membawa beberapa video tentang sekolah, ataupun banner, namun mereka juga melibatkan siswa-siswi yang berasrama atau para alumni dari SMP yang dikunjungi untuk memberikan testimony atau pengakuan yang positif tentang belajar dan tinggal di asrama SMA Sedes Sapientiae Jambu. Melalui hal ini maka akan menarik minat para siswa-siswi SMP untuk mengetahui bagaimana belajar hidup mandiri, bagaimana tinggal di asrama bersama-sama. Hal ini terbukti ampuh karena dalam beberapa kali presentasi di SMP, banyak siswa-siswi SMP yang kemudian menanyakan lebih lanjut kepada siswa-siswi SMA Sedes Sapientiae Jambu yang melakukan testimony tentang asrama, guru-gurunya, pelajarannya dan lain sebagainya dengan santai dan bahkan seperti mengobrol dengan teman sendiri.

Selain dengan memasang spanduk, safari koor, dan presentasi ke beberapa SMP di Jabodetabek maupun di area Jawa Tengah dan Yogyakarta, SMA Sedes Sapientiae juga memiliki hubungan yang baik dengan para alumninya. Melalui para alumni yang telah sukses akan diminta testimony atau kesaksian ketika mereka bersekolah di Sedes Sapientiae Jambu, dan bagaimana suka duka hidup di asrama bersama. Dalam kesaksian tersebut beberapa alumni secara tidak langsung akan membuat para calon siswa - siswi SMA Sedes Sapientiae Jambu merasa bahwa sekolah ini memang sekolah yang baik, bermutu dan disiplin. Dengan kesaksian para alumni ini akan sangat membantu mempromosikan sekolah dan bisa menarik minat para calon pendaftar. 
Dengan menjalin hubungan yang baik dengan para alumni dan juga bekerja sama dengan beberapa SMP baik yang berada di Jawa Tengah maupun di Jabodetabek merupakan kunci keberhasilan dari strategi pemasaran SMA Sedes Sapientiae Jambu. Melalui relasi yang baik ini maka SMA Sedes Sapientiae Jambu ini pun juga terbantu untuk mempromosikan sekolah karena, dari pihak alumni maupun pihak SMP juga membantu mengarahkan para siswa-siswiny untuk bersekolah di SMA Sedes Sapientiae Jambu, selain itu para alumni dan juga para guru dan staff dari SMP yang memiliki kerja sama dengan SMA Sedes Sapientiae Jambu pun juga mendorong dan meyakinkan para calon siswa SMA untuk masuk dan bersekolah di SMA Sedes Sapientiae Jambu. Melalui kerja sama dan relasi yang baik dengan para alumni yang saat ini telah tersebar di berbagai daerah maka para alumni pun akan merekomendasikan SMA Sedes Sapientiae Jambu sebagai sekolah lanjutan berasrama yang baik, sehingga akan ada banyak murid dari berbagai daerah akan datang ke SMA Sedes Sapientiae Jambu.

Menurut hasil wawancara dengan tim PSB, banyak orang tua murid yang berasal dari luar Semarang ataupun dari luar Jawa mengetahui SMA Sedes Sapientiae Jambu dari para alumni ataupun dari orang tua dan keluarga alumni dan siswa yang bersekolah di SMA Sedes Sapientiae Jambu, baik alumni tersebut masih ada ikatan keluarga atau saudara maupun tetangga para orang tua murid. Melalui para alumni yang secara tidak langsung membantu mempromosikan SMA Sedes Sapientiae Jambu dan menceritakan kisah para alumni selama bersekolah di SMA Sedes Sapientiae Jambu (testimony) para orang tua muridpun menjadi penasaran dan mencari tahu mengenai SMA Sedes Sapientiae Jambu dan tertarik serta terdorong untuk menyekolahkan anak mereka ke SMA Sedes Sapientiae Jambu.

Melalui beberapa strategi tersebut SMA Sedes Sapientiae Jambu pun mengalami peningkatan dalam jumlah muridnya setiap tahunnya. Bahkan untuk semakin meningkatkan kinerja tim promosi, SMA Sedes Sapientiae Jambu tak segan untuk belajar mengenai marketing yang baik dengan mengundang seorang ahli marketing dari Semarang. Dari beberapa strategi tersebut, ada satu hal yang masih kurang optimal, yaitu hubungan dengan alumni. Untuk alumni, SMA Sedes Sapientiae Jambu telah membentuk persatuan alumni SMA Sedes Sapientiae Jambu, namun belum semua alumni terdaftar, dan 
pada tahun 2015 yang lalu para alumni secara resmi membentuk ikatan alumni SMA Sedes Sapientiae Jambu, dan para siswa-siswi yang lulus pada tahun 2015 kemarin juga secara otomatis masuk dalam ikatan alumni tersebut. Sedangkan alumni-alumni yang sudah lama dan bahkan sudah tersebar di berbagai kota sedang dalam proses untuk dihubungi melalui alumni-alumni yang sudah bergabung dan juga melalui pihak sekolah yang juga berusaha menghubungi para alumni untuk bergabung dalam ikatan alumni SMA Sedes Sapientiae Jambu. Ikatan alumni ini tidak hanya sekedar wadah bagi para alumni untuk bertemu satu sama lain, melainkan juga untuk saling membantu sama lain, seperi jika ada adik angkatan yang sedang mencari pekerjaan makan kakak-kakak alumni dapat membantu untuk mencari pekerjaan, selain itu para alumni ini juga dapat membantu mempromosikan SMA Sedes Sapientiae Jambu secara langsung, baik ditempat kerja ataupun lingkungan rumah dan gereja.

Pelaksanaan strategi pemasaran ini tentunya mendapatkan pengawasan dari Kepala Sekolah dan juga wakil kepala sekolah bagian kesiswaan dibantu oleh komite sekolah. Dalam hal ini, Kepala Sekolah, wakil kepala sekolah dan komite mengawasi jalannya kegiatan promosi sekolah dan bertanggung jawab atas berjalannya kegiatan tersebut. Kemudian, Kepala Sekolah, wakil kepala sekolah dan juga tim promosi akan mengadakan evaluasi setelah mereka selesai melakukan kegiatan promosi. Kegiatan evaluasi ini dilakukan dengan harapan, jika ada kesalahan atau keunggulan dalam kegiatan promosi dapat diperbaiki dan juga lebih ditingkatkan untuk kegiatan promosi yang selanjutnya.

\section{SIMPULAN DAN SARAN}

Berdasarkan hasil penelitian tersebut dapat dilihat bahwa dalam menentukan dan melaksanakan promosi sekolah, SMA Sedes Sapientiae Jambu merencanakannya dengan matang dan terperinci. Kegiatan-kegitan yang dilakukan juga beragam baik secara internal ataupun eksternal, yaitu dengan mengadakan open house, lomba antar SMP, memasang spanduk, safari koor, promosi ke sekolah-sekolah di beberapa sekolah di Jawa Tengah, Yogyakarta dan Jabodetabek, serta adanya kerja sama dengan berbagai SMP di berbagai daerah dan juga relasi yang baik dengan alumni. 
Kunci keberhasilan dari strategi pemasaran atau promosi SMA Sedes Sapientiae Jambu ini berasal dari dalam diri SMA Sedes Sapientiae Jambu sendiri, dimana internalnya kuat makan kegiatan eksternalnya juga akan kuat. Salah satu kekuatan dari internal SMA Sedes Sapientiae Jambu adalah dengan menghasilkan lulusan yang bermutu dan pengajaran para guru yang berlandaskan dengan kasih. Selain itu, relasi dan kerja sama yang baik antara SMA Sedes Sapientiae Jambu dengan warga sekitar, komite, orang tua murid, SMP di berbagai daerah dan juga para alumni menjadi bekal yang baik untuk mempermudah melakukan promosi atau pemasaran sekolah di berbagai daerah.

Melalui penelitian Best Practice ini, penulis menyarankan kepada sekolah-sekolah lain yang ingin meningkatkan strategi pemasaran atau promosi sekolah dengan menjalin kerja sama dan membangun relasi yang baik dengan warga sekitar, orang tua murid, komite, dan juga alumni, selain itu menjalin kerja sama dengan SMP-SMP yang ada disekitar sekolah juga merupakan hal yang penting untuk mendapatkan murid dari SMP tersebut. Promosi yang unggul sebetulnya adalah promosi dari para alumni dan kesaksian dari para alumni, orang tua murid serta warga sekitar, karena mereka mengalami langsung dan mengetahui dengan baik mengenai sekolah yang bersangkutan. Selain itu, hal terpentingnya adalah membangun internal yang kuat, baik dari segi sapras, kesiswaan, kurikulum dan lain sebagainya.

\section{DAFTAR PUSTAKA}

Alma, B. (2005). Pemasaran Stratejik Jasa Pendidikan. Bandung: Alfabeta.

Alma, P. D. (2009). Manajemen Pemasaran dan Pemasaran Jasa. Bandung: Alfabeta.

Indhira Gandhi National Open University. (2004). Marketing of Services. New Delhi: Akashdeep Printers, Darya Ganj.

Inyah. (2012). Peranan Promosi dalam Membentuk Opini Calon Mahasiswa. Ragam Jurnal Pengembangan Humaniora Vol 12 No. 3 Desember, 179 - 186.

Sinduwiatmo, R. G. (2011). Pengaruh Promosi Sekolah Terhadap Keputusan Siswa Dalam Pemilihan Smk Sepuluh Nopember Sidoarjo. Kanal Jurnal Ilmu Komunikasi, 27 - 28.

Suharsimi Arikunto dan Safrudin Cepi Abdul Jabar. (2009). Evaluasi Program Pendidikan. Jakarta: Bumi Aksara.

Wijaya, D. (2012). Pemasaran Jasa Pendidikan. Jakarta : Salemba Empat.

Yuliana, S. A. (2009). Manajemen Pendidikan. Yogyakarta: Aditya Media dan Fakultas Ilmu Pendidikan UNY. 